\title{
Importance of maintaining redox potential balance in the development of type 2 diabetes
}

\author{
Hava Rozenfeld ${ }^{1,2}$, Moria Chetboun 1,2, Sanford R Sampson²,3, Tovit Rosenzweig ${ }^{1 *}$ \\ From Metabolism, diet and disease \\ Washington, DC, USA. 29-31 May 2012
}

\begin{abstract}
Background
Accumulation of ROS leads to oxidative stress, which is a common denominator in many diseases. As a result of promising results obtained from in-vitro and in-vivo studies showing the beneficial function of antioxidants in the prevention of diseases, including benefits of antioxidants on insulin sensitivity and $\beta$-cell viability and function, supplementation of antioxidants became very popular. Unfortunately, major randomized clinical trials have yielded disappointing results. Meta analyses conclude that antioxidant supplementations have no beneficial effects on the prevalence of type 2 diabetes (T2D). There are several possible explanations for the failure of antioxidant supplementation to improve health outcomes. Our hypothesis is that there is an optimal redox state that should normally be maintained in cells. If shifted either to the oxidized or to the reduced state, disturbances in $\beta$-cell function and in insulin sensitivity of target tissues appear. The aim of this study is to clarify the correlation between redox potential and the development of diabetes.
\end{abstract}

\section{Materials and methods}

Both in-vitro and in-vivo experiments were conducted. Invitro study was performed on insulinoma RinM and Min6 cell lines. The effects of $\mathrm{H}_{2} \mathrm{O}_{2}$ and the antioxidant $\mathrm{N}$ acetyl-L-cysteine (NAC) at different concentration were investigated on insulin secretion, viability of $\beta$-cells and mRNA expression of specific $\beta$-cell transcription factors. In-vivo experiments were conducted on $\mathrm{KK}-\mathrm{A}^{\mathrm{y}}$ mice, a known model of T2D. Mice were given NAC at different concentrations (200-1800 mg/kg/day) during adulthood. Diabetes was evaluated in treated mice by glucose and insulin tolerance tests, histological studies of pancreatic $\beta$ cells; insulin signaling pathway was followed in muscle

'Department of Molecular Biology, Department of Nutritional Studies, Ariel University Center, Israel

Full list of author information is available at the end of the article tissue, and several analyses were determined in plasma (insulin, TBARS, TG, cholesterol).

\section{Results}

In-vitro experiments show that, whereas high concentrations of $\mathrm{H}_{2} \mathrm{O}_{2}(>10 \mu \mathrm{M})$ induce oxidative stress and pancreatic $\beta$-cell death, low concentrations $(4 \mu \mathrm{M})$ increased viability of these cells, and basal and glucose-induced insulin secretion. High concentrations of NAC reduced viability of cells [1]. mRNA expression of Pdx1 and Pax4 is regulated by the redox state of cells. In-vivo results show that while 600,1200 and $1800 \mathrm{mg} / \mathrm{kg} /$ day NAC were all found to improve glucose tolerance of mice, the $1200 \mathrm{mg} /$ $\mathrm{kg} /$ day treatment was the most effective in improving insulin sensitivity as indicated by low HOMA-IR. This study clarifies the dose-response effect of NAC on the development of diabetes, and on other manifestations of the metabolic syndrome.

\section{Conclusions}

We conclude that alterations in redox balance, resulting from oxidative stress as well as oversupply of antioxidants, may lead to disturbances in the function of pancreatic $\beta$-cells and of insulin target tissues.

The study clarifies the beneficial effects of NAC on insulin sensitivity and $\beta$-cell function, and suggests that excessive antioxidant consumption has deleterious effects on the development of diabetes. This may provide an explanation for the failure of intervention studies to achieve beneficial health outcomes, and may lead to personalizedadjusted consumption of antioxidants.

\footnotetext{
Author details

'Department of Molecular Biology, Department of Nutritional Studies, Ariel University Center, Israel. ${ }^{2}$ Faculty of Life Sciences, Bar-llan University, RamatGan, Israel. ${ }^{3}$ Department of Molecular Cell Biology, Weizmann Institute of Science, Rehovot, Israel.
} 
Published: 1 June 2012

\section{Reference}

1. Chetboun M, Abitbol G, Rozenberg K, Rozenfeld H, Deutsch A, Sampson SR, Rosenzweig T: Maintenance of redox state and pancreatic beta-cell function: role of leptin and adiponectin. J Cell Biochem 2012.

doi:10.1186/1753-6561-6-S3-P39

Cite this article as: Rozenfeld et al:: Importance of maintaining redox potential balance in the development of type 2 diabetes. BMC

Proceedings 2012 6(Suppl 3):P39.

Submit your next manuscript to BioMed Central and take full advantage of:

- Convenient online submission

- Thorough peer review

- No space constraints or color figure charges

- Immediate publication on acceptance

- Inclusion in PubMed, CAS, Scopus and Google Scholar

- Research which is freely available for redistribution

Submit your manuscript at www.biomedcentral.com/submit
Ciomed Central 